$\begin{array}{r}\text { Volume and Issues Obtainable at Center for Sustainability Research and Consultancy } \\ \text { Journal of Accounting and Finance in Emerging Economies } \\ \text { ISSN: 2519-0318 ISSN (E) 2518-8488 } \\ \text { Volume 5: Issue 1 June 2019 } \\ \text { CSRC } \\ \text { Journal homepage: www.publishing.globalcsrc.org/jafee } \\ \hline\end{array}$

\title{
Assessment of Human Resource Management Model in Islamic Banking of Pakistan With Moderating Role of Islamic Principles
}

\author{
${ }^{1}$ Danish Iqbal Godil, ${ }^{2}$ Muhammad Umer Quddoos, ${ }^{3}$ Liaquat Ali \\ ${ }^{1}$ Bahria University, Karachi Campus, Email: danishiqbal.bukc@bahria.edu.pk \\ ${ }^{2}$ Assistant Professor, Department of Commerce, Bahauddin Zakariya University, Multan, Pakistan. \\ Email: umerattari@bzu.edu.pk \\ ${ }^{3}$ Bahria University, Karachi Campus, Email: liquatali.bukc@bahria.edu.pk
}

\begin{tabular}{l}
\hline \multicolumn{1}{c}{ ARTICLE DETAILS } \\
\hline History \\
Revised format: May 2019 \\
Available Online: June 2019 \\
\\
\hline Keywords \\
Islamic Principles, HR Practices, \\
Organizational Performance, \\
Islamic Banks
\end{tabular}

JEL Classification:

M10,M12

\begin{abstract}
The objective of the study is to analyze the role of human resource practices on organizational performance with the moderating effect of Islamic principle application in the Islamic banks of Pakistan. Responses from 242 employees of Islamic banks located in Karachi, Pakistan, were collected using convenience sampling technique while PLS-SEM has been employed for data analysis using Smart PLS version 3.2.8. Results showed that employee involvement, performance appraisal system, and selection and recruitment have significant positive relationship with organizational performance; whereby, compensation, and training and development have no relationship with organizational performance. Furthermore, compensation. Training \& development, selection and recruitment has improved whereas performance appraisal system has reduced its relationship with organizational performance due to the moderating effect of application of Islamic principles. Employee's involvement may have reduced, i.e., it showed insignificant impact on organizational performance due to the moderating effect of Islamic principles' application. We suggest the managers of islamic banks to provide greater focus on the training and development side of the organization. This is so because, when a company provides relevant training to the employees, only then they would be able to perform their job in a proper way and as per the expectations of the management. Application of Islamic principles need to be coupled with providing monetary benefits as it motivates them to perform more actively and accurately.
\end{abstract}

(C) 2019 The authors, under a Creative Commons Attribution-Non

Commercial 4.0

Corresponding author's email address: umerattari@bzu.edu.pk

Recommended citation: Godil, D. I., Quddoos, M. U. and Ali, L. (2019). Impact Assessment of Human Resource Management Model in Islamic Banking of Pakistan With Moderating Role of Islamic Principles. Journal of Accounting and Finance in Emerging Economies, 5 (1), 23-32

DOI: $10.26710 /$ jafee.v5i1.721 


\section{Introduction}

Scholars of management sciences have extensively supported the acceptance of highly determined human resource (HR) actions for the better execution of firms' operations. According to current researches, such actions have contributed much towards the firms' achievements and therefore, regarded as "high performing resources" operations (Mostafa, Gould-Williams, \& Bottomley, 2015). A model of HRM-performance explores how HRM training, reward, selection, job design, involvement practices and reward lead to involvement, employee effort, discretionary behavior and co-operation which results in enhanced individual performance, better ROI and higher organizational profits (Albrecht, Bakker, Gruman, Macey, \& Saks, 2015).Moreover, this model further claimed that the strategic HR operations is an interconnected system, which intensifies the performance of human capital differently as being encountered with a combination of other organizational strategies and the results are varied from firm to firm. In other words, these combinations add values to the firms in various ways, such as by means of untying new synergies or stimulating higher cost-reduction (Darwish, Singh, \& Wood, 2016).

However, without tailoring those HR practices for local environment and in terms of domestic value system and arrangements, business organization may not be able to take favorable results from HR practices, leading to downsizing, workload and lack of managerial control; ultimately, organizational performance may not be achieved ( Rana \& Malik, 2016). Certainly, another aspect of these issues is basically the cultural barriers which hinders the desirable outcomes from HR practices (Rana \& Malik, 2017b). Since the idea of being human varies significantly between materialistic schools of thoughts and Islam, human resource management (HRM) in Islamic cultures would be different in Islamic nations (Fesharaki \& Sehhat, 2018). Teachings the Holy Quran and Sunnah can be extremely significant in shaping an amiable work environment. Islamic countries are now embarking upon the problem by investigating the pious duties and norms in face of management solutions following by the western world. These are the challenges that are particularly obvious in human management operations. From this point, in the literature of Islamic firms, the idea of Islamic human resource management (IHRM) has been unfolded and according to it, the relationship and communication between the employees and the employer should follow the principles laid down by the Holy Quran and Sunnah (Fesharaki \& Sehhat, 2018). This concept leads to the implementation of an Islamic Model while keeping in view the Islamic principles that have high regard towards Muslims and which is more efficient conflict management tool amongst a Muslim workforce.

Moreover, managers will recognize the Islamic principles in much better way and work accordingly, so that they can maximize the firm performance. The versatile nature of these principles made the Islamic model prominent and adaptable to such extent that, non-Muslims expatriates also inducing it into their environment (Abdul Cader, 2017). Therefore the objective of the study is to assess HRM model with the moderating effect of Islamic principle application in the Islamic banks of Karachi, Pakistan.

\section{Literature Review}

Hussain \& ur Rehman (2013) examined the relationship between HRM practices and employees retention. The study concludes that, execution of HRM practices would lead towards retaining of super keepers of the organization Razimi et al. (2014) focused on the dimensions of HRM from the Islamic point of view. The study highlights the presence of Islamic framework for some of the operations of HRM. Recruitment and selection, compensation, knowledge management, leadership and employee relations were studied in the light of the Islamic perspectives. The study explains that, according to the Islamic teachings the concept of job fit is essential, the person should be hired on the basis of his capabilities i.e. concept of right person for the right job. The study highlighted the religious influences on HR. R. L. Dhar, (2015) focused on identifying the impact of IHRM practices on Islamic banks' performance through the organizational commitment. It was identified that the Islamic practices of HR has significant effects on the organizational performance with the help of organizational commitment. The study suggests that the Islamic Banks have to work on the Islamic HR practices to maintain their performance in the organizations. This research also examined the intervening impact of the climate on the relationship between service innovation behavior and the commitment related innovation. The results showed that there is a mediating impact of organizational commitment on the relationship between service innovative behavior of employees and the HPHRP. Further the innovation climate works as a moderator in association between the service innovative behavior and the organizational commitment.

According to Darwish et al., (2016) HR practices have great impact on the subjective and objective performance. Saleem, Malik, \& Khattak, (2016) conducted a research to shed light on the principles of Islam for the effective management of human resource. The study shows that the basis of Islamic management is the mutual trust between 
the managers and their subordinates. Suib \& Said, (2017) identified the relationship between the Islamic concept of spirituality and the Islamic work ethics. They found that the Islamic work ethics has positive impact on the workers power, service quality and customer loyalty. According to them Islamic Spirituality brings positive energy and ultimately it increases performance. Rana \& Malik, (2017a) conducted a research to understand the effects of HR practices on the performance of mobile telecommunication service providers with Islamic principles as moderating variable. The study also investigated the moderating impact of Islamic principles. The results indicated that the HR practices such as employee participation, training, selection, performance appraisal and the compensation have positive and significant impact on the performance of business. Islamic principles also showed moderating and positive impact. Knies, Boselie, Gould-Williams, \& Vandenabeele, (2017) did an empirical and conceptual study on the subject of strategic HRM and the performance of public sector companies. The findings revealed that the strategic HRM has significant positive impact on both the motivation of employees and the performance of organization.

Perceived organizational support (POS) has significant impact on the satisfaction of employees and it works as a mediator between the particular HR practices and the employees' satisfaction (Bronston et al. 2017). Madison, Daspit, Turner, \& Kellermanns, (2018) conducted a research to investigate the treatment with employees in family and non-family organizations and how it effects the performance of firms. Results revealed that that the HR professionalization is positively associated with the performance of family firms. Fesharaki \& Sehhat (2018) conducted a study on bank of tehran to present and stimulate the original idea of IHRM. They analyzed its impact on two attitudes of organizations i.e. commitment of employees and the perceived justice. It was found by them that IHRM has positive impact on the organizational justice and commitment of employees. B. K. Dhar et al., (2018) explored the effects of IHRM practices with organizational commitment on the performance of six different Islamic listed banks. The analysis showed that, with organizational commitment, the practices of Islamic HR have higher significant effect on the performance of organizations rather than the having direct impact of Islamic practices of HR on the organizational performance. The outcomes revealed that the Islamic banks must focus on the Islamic HR related practices and commitment with organizations in order to improve the overall performance of the employees as well as the company.

\section{Research Methodology}

Quantitative approach usually focuses on measurability, relationship assessment and quantifying the undertaken phenomenon based on numbers and statistical expressions (Cohen, Manion, \& Morrison, 2013). In the current research study, measurable data and statistical techniques were used to analyze the pre-existing phenomenon and aimed to provide keen and implicative findings to contribute into literature and practice and therein, quantitative research approach has been adopted in the study. This study will fall under the category of explanatory research as it was intended to re-examine and clarifying the previously established and well-known phenomenon with some sort of changes for enriched outcomes.

\subsection{Sample Size \& Sampling Technique}

The target population of this study is employees of Islamic banks of Karachi, Pakistan. Therefore, responses were collected from the HR professionals of Karachi-based Islamic banks of Pakistan. The study has used sample size estimation formula of N10 as recommended by Hair, Black, Babin, Anderson, and Tatham (2010) where N is the total number of variables. In this regards, the study has total 7 variables so that minimum sample required for the study was found as 70 . Henceforth, the study has gathered 242 sample responses from the target population. Purposive sampling basically deals with the selection of respondents based on the expertise and knowledge of the researcher and inclusion criterion made by the researcher (Zikmund, Babin, Carr, \& Griffin, 2013). Henceforth, the study has used purposive sampling technique.

\subsection{Data Collection and Analysis}

First-hand data was collected from primary sources such as, respondents and social actors associated with the undertaken phenomenon and horizon. So sample data was particularly taken from the HR professionals of Islamic Banks of Karachi, Pakistan. Moreover, primary data sources i.e. five-point Likert scale questionnaire was utilized as a data collection instrument, while the measures of each construct were adapted from previous published literature and empirical studies e.g. (Delaney \& Huselid, 1996; Ali \& Al-Owaihan, 2008; Hashim, 2009; Azmi, 2010; Moideenkutty et al. 2011; Sarwar and Abugre, 2013; Amin et al. 2014; Al-Quda et al. 2014) 
The study has developed complex and multi-layered conceptual framework using comparatively smaller sample size. Hence, the study has purposefully used PLS-SEM as data analysis technique. After demographic analysis, initially reliability and validity was figured out. Secondly Path analysis was done along with testing the moderating impact of Islamic principles between HRM practices and performance of Islamic Banks.

\section{Data Analysis}

\subsection{Demographic Statistics}

The total of 242 respondent participated in this research. Descriptive statistics of these respondents are as follows.

Table I: Demographic Statistics $(n=242)$

\begin{tabular}{llll}
\hline & & Frequency & Percent \\
\hline \multirow{3}{*}{ Experience level (years) } & 1 to 5 & 151 & 62.4 \\
& 5 to 10 & 70 & 28.9 \\
& 11 to 15 & 14 & 5.8 \\
& More than 15 & 7 & 2.9 \\
Age group (years) & Less than 30 & 14 & 5.8 \\
& 30 to 39 & 130 & 53.7 \\
& 40 to 49 & 91 & 37.6 \\
Education & 50 and above & 7 & 2.9 \\
& Diploma & 70 & 28.9 \\
Gender & Bachelor degree & 42 & 17.4 \\
& Master degree & 63 & 26.0 \\
& Others & 67 & 27.7 \\
& Female & 119 & 49.2 \\
& Male & 123 & 50.8 \\
\hline
\end{tabular}

\subsection{Outer Loadings}

Construct validity is one of the most important concepts in management, social and behavioral sciences. In regards to construct validity using PLS-SEM, numerous scholars and authors have manifested that factor loadings/outer loadings of the items should be atleast 0.60 as an appropriate cutoff/threshold (Hair, Ringle, \& Sarstedt, 2011; Hair, Sarstedt, Hopkins, \& G. Kuppelwieser, 2014; Ringle, Sarstedt \& Straub, 2012; Wong, 2013). Therefore, on the scholarly manifested discussion about threshold for construct validity; the following table III provides result of construct validity of the current research study. Hence, Table II clearly demonstrated that all the measures have factor loadings greater than 0.60 . Hence, construct validity for current study has been achieved considerably.

\subsection{Convergent Validity}

Convergent validity measures the degree of convergence among measures of particular construct. In following Table II, results of convergent validity including composite reliability and AVE have been provided.

\section{Table 2: Factor Loading, CR \& AVE.}




\begin{tabular}{|c|c|c|c|c|c|c|c|c|c|c|}
\hline & AIP & COMP & EI & PAS & PER & SR & TD & $\alpha$ & CR & AVE \\
\hline Application of Islamic Principles_AIP7 & 0.833 & & & & & & & 0.703 & 0.830 & 0.621 \\
\hline Application of Islamic Principles_AIP8 & 0.811 & & & & & & & & & \\
\hline Application of Islamic Principles_AIP9 & 0.714 & & & & & & & & & \\
\hline Compensation_COMP4 & & 0.929 & & & & & & 0.860 & 0.934 & 0.877 \\
\hline Compensation_COMP5 & & 0.944 & & & & & & & & \\
\hline Employee Involvement_EII & & & 0.916 & & & & & 0.824 & 0.882 & 0.657 \\
\hline Employee Involvement_EI2 & & & 0.755 & & & & & & & \\
\hline Employee Involvement_EI3 & & & 0.638 & & & & & & & \\
\hline Employee Involvement_EI4 & & & 0.900 & & & & & & & \\
\hline Performance Appraisal System_PAS1 & & & & 0.683 & & & & 0.762 & 0.842 & 0.573 \\
\hline Performance Appraisal System_PAS3 & & & & 0.699 & & & & & & \\
\hline Performance Appraisal System_PAS4 & & & & 0.832 & & & & & & \\
\hline Performance Appraisal System_PAS5 & & & & 0.803 & & & & & & \\
\hline Organizational Performance_PERF1 & & & & & 0.953 & & & 0.906 & 0.955 & 0.914 \\
\hline Organizational Performance_PERF2 & & & & & 0.959 & & & & & \\
\hline Selection and Recruitment_SRI & & & & & & 0.735 & & 0.753 & 0.722 & 0.566 \\
\hline Selection and Recruitment_SR4 & & & & & & 0.769 & & & & \\
\hline Training and Development_TD2 & & & & & & & 0.734 & 0.844 & 0.879 & 0.595 \\
\hline Training and Development_TD3 & & & & & & & 0.848 & & & \\
\hline Training and Development_TD4 & & & & & & & 0.611 & & & \\
\hline Training and Development_TD5 & & & & & & & 0.850 & & & \\
\hline Training and Development_TD6 & & & & & & & 0.789 & & & \\
\hline
\end{tabular}

For satisfactory results of convergent validity, it is suggested by Hair, Black, Babin, Anderson and Tatham (2006) that average variance extracted and composite reliability for every variables must be higher than 0.50 and 0.70 accordingly. Thus, in Table II above, all the latent constructs have achieved satisfactory internal consistency and degree of convergence as per the suggested thresholds.

\subsection{Discriminant Validity}

The criterion proposed by Fornell and Larcker (1981) along with the method known as Heterotrait-Monotrait (HTMT) Ratio are the two constituents forming the evaluative measurements for establishing discriminant validity in the PLS structural equation modeling. It confirms validity as recommended by (Henseler, Hubona \& Ray, 2016; Henseler, Ringle, \& Sartedt, 2015) particularly for structural equation modeling oriented by partial least square estimation of models.

\section{Table 4: Fornell-Larcker Criterion}

\begin{tabular}{llllllll}
\hline & AIP & COMP & EI & PERF & PAS & SR & TD \\
\hline Application of Islamic Principles & 0.788 & & & & & & \\
Compensation & 0.056 & 0.936 & & & & & \\
Employee Involvement & 0.073 & 0.601 & 0.810 & & & & \\
Organizational Performance & 0.164 & 0.549 & 0.813 & 0.956 & & & \\
Performance Appraisal System & 0.001 & 0.341 & 0.605 & 0.689 & 0.757 & & \\
Selection and Recruitment & -0.060 & 0.275 & 0.112 & 0.239 & 0.085 & 0.752 & \\
Training and Development & 0.033 & 0.397 & 0.498 & 0.642 & 0.772 & 0.333 & 0.772 \\
\hline
\end{tabular}

According to Fornell and Larcker (1981), the AVE's square-root for each underlying construct has to be bigger than their particular association coefficients of further elements to attain substantial distinguish validity. The table 
IV shows that all underlying constructs have attained substantial unique validity and their individual participation in the current model.

Table 5: Heterotrait-Monotrait Ratio (HTMT)

\begin{tabular}{llllllll}
\hline & AIP & COMP & EI & PERF & PAS & SR & TD \\
\hline Application of Islamic Principles & & & & & & & \\
Compensation & 0.106 & & & & & & \\
Employee Involvement & 0.095 & 0.703 & & & & & \\
Organizational Performance & 0.199 & 0.618 & 0.894 & & & & \\
Performance Appraisal System & 0.174 & 0.395 & 0.706 & 0.767 & & & \\
Selection and Recruitment & 0.364 & 0.652 & 0.337 & 0.521 & 0.852 & & \\
Training and Development & 0.131 & 0.364 & 0.491 & 0.613 & 0.830 & 0.713 & \\
\hline
\end{tabular}

HTMT ratio offers one more narrative measure of assessing unique validity as projected by Henseler et al. (2015), which states that all HTMT ratios have to be under 0.90 for unique validity and by this means Table V illustrates that all underlying constructs had found to be distinguished apart, irrespective of other constructs as considered in the current modeling structure and consequently, HTMT ratio has been attained by using unique validity.

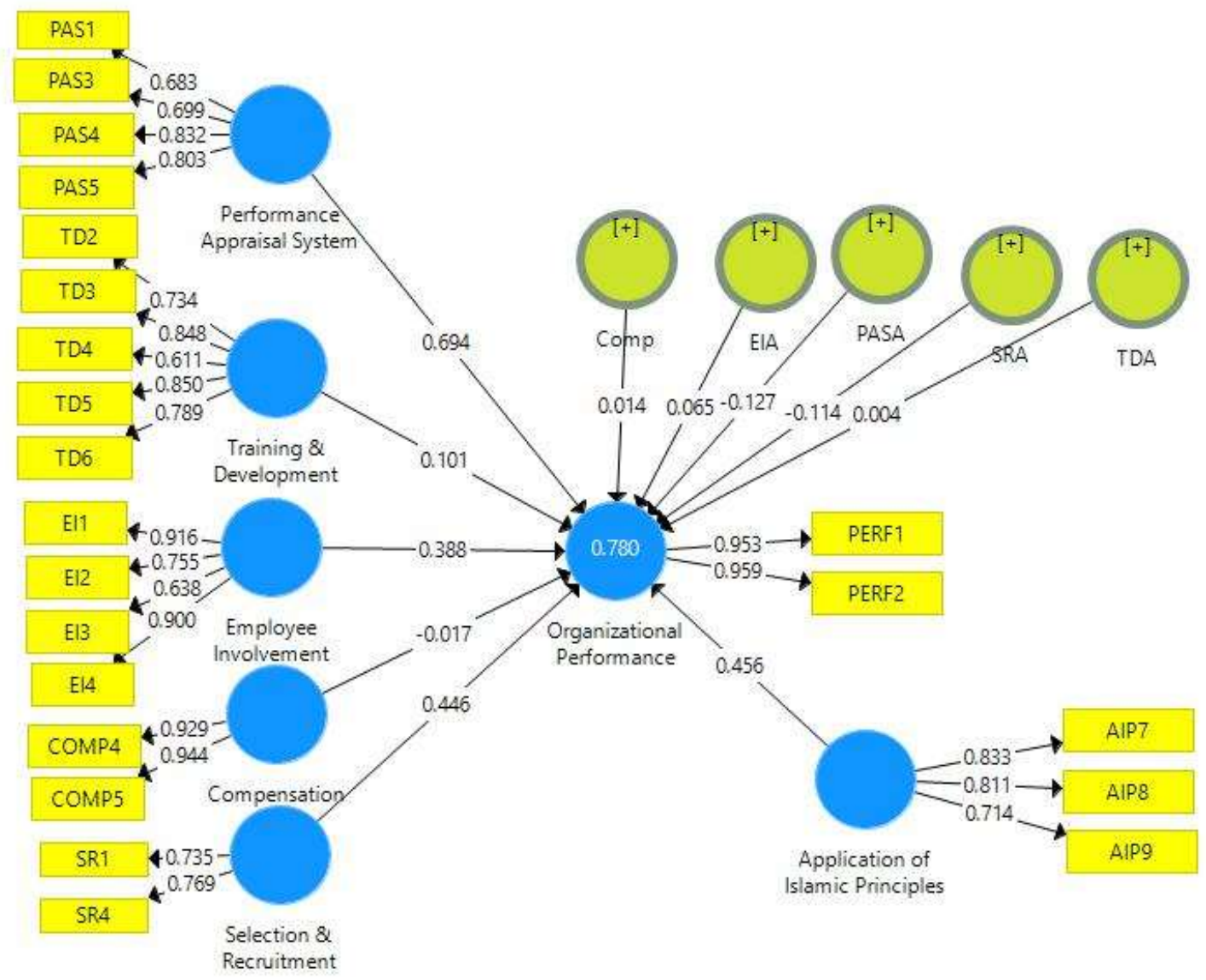

\section{Figure 2: Modelling Framework}

\subsection{Path Analysis}

Table VI showed that employee involvement $(0.388, \mathrm{p}<0.10)$, performance appraisal system $(0.694, \mathrm{p}<0.05)$ and selection and recruitment $(0.446, \mathrm{p}<0.10)$ have significantly positive relationship with organizational performance; 
whereby, compensation $(-0.017, \mathrm{p}>0.929)$ and training and development $(0.101, \mathrm{p}>0.05)$ have no relationship with organizational performance.

\section{Table 6: Path Coefficient}

\begin{tabular}{lllll}
\hline & Estimate & S.D. & T-Stats & Prob. \\
\hline Compensation -> Organizational Performance & -0.017 & 0.192 & 0.089 & 0.929 \\
Employee Involvement -> Organizational Performance & 0.388 & 0.231 & 1.681 & 0.093 \\
Performance Appraisal System -> Organizational Performance & 0.694 & 0.261 & 2.655 & 0.008 \\
Selection and Recruitment -> Organizational Performance & 0.446 & 0.255 & 1.748 & 0.081 \\
Training and Development -> Organizational Performance & 0.101 & 0.317 & 0.319 & 0.750 \\
\hline
\end{tabular}

\subsection{Moderation Analysis}

Following Table VII provides moderation analysis using PLS-SEM; wherein, the analysis have undertaken the moderating effect of "application of Islamic principles" on the relationship between independent and dependent constructs.

\section{Table 7: Moderation Analysis}

\begin{tabular}{lllll}
\hline Moderator: Application of Islamic Principles & Estimate & S.D. & T-Stats & Prob. \\
\hline Compensation -> Organizational Performance & 0.074 & 0.042 & 1.777 & 0.076 \\
Employee Involvement -> Organizational Performance & -0.070 & 0.055 & 1.275 & 0.202 \\
Performance Appraisal System -> Organizational Performance & 0.174 & 0.071 & 2.462 & 0.014 \\
Selection and Recruitment -> Organizational Performance & -0.094 & 0.045 & 2.097 & 0.036 \\
Training and Development -> Organizational Performance & -0.155 & 0.055 & 2.806 & 0.005 \\
\hline
\end{tabular}

Above table showed that the relationship between compensation $(0.074, \mathrm{p}<0.10)$, performance appraisal system $(0.174, p<0.05)$, selection and recruitment $(-0.094, p<0.05)$, training and development $(-0.155, p<0.05)$ with organizational performance may be moderated by the application of Islamic principles. However, the relationship of employee involvement $(-0.070, \mathrm{p}>0.05)$ with organizational performance may not be moderated by the application of Islamic principles.

\subsection{R-Square}

Following table VIII provides result of R-square for explaining predictive power of the outcome construct in the model. Herein, R-square and adjusted R-square have been reported using PLS algorithm technique.

Table VIII: R Square

\begin{tabular}{lll}
\hline & R Square & R Square Adjusted \\
\hline Organizational Performance & 0.793 & 0.783 \\
\hline
\end{tabular}

Above table shows that the combine effect of training and development, compensation, selection and recruitment, employee involvement, performance appraisal system and application of Islamic principles can explain organizational performance up to 79.3 percent.

\section{Discussion}

The results indicate that the HR practices such as practices including, employee participation, selection and recruitment, performance appraisal have positive and significant impact (Albrecht et al; 2015; Rana \& Malik, 2017a; Fesharaki \& Sehhat, 2018) whereas compensation (Mbogho, 2012), training and development has no significant impact on the organizational performance. Success in training is contingent on the technique used by training and its content (Driskell 2011). According to Birdi (2005) influence of creative training could be refrained due to lack of managerial support. Additionally effectiveness of training is influences by absence of proper environment. 
Further Islamic principles showed mix moderating significant results (Abdul Cader, 2017) i.e. positive in case of compensation and performance appraisal (Rana \& Malik, (2017a) but negative in case of selection and training. The negative sign is might be due to the sample size as Islam stresses on competency and merit in selection of employee and it shall not biased due to race, kinship, friendship and wealth etc.(Alorfi, 2012). Selecting employees according to Islamic principles improves employees' morale and ultimately leads towards improvement of the business. In case of employee involvement the relationship becomes insignificant due to moderating effect of Islamic principles. The result is again insignificant due to the limited sample size and is not in line with researchers i.e. (Hashim, 2010; Salleh, 2012). Islam supports involvement of employees in decision making and permits productive criticism on policies of organization (Rana \& Malik, 2017).

\section{Recommendations and Conclusion}

The objective of the study was to analyze the role of human resource practices on organizational performance with the moderating effect of Islamic principle application in the Islamic banks of Karachi, Pakistan. SEM was used to analyze the impact of recruitment and selection, training and development, compensation, performance appraisal and employee involvement on organizational performance. The outcomes of the study reveal that employee involvement is an essential indicator to improve the overall organizational performance. Moreover, the researcher found performance appraisal, selection and recruitment as important factors to enhance the organizational performance. However, due to limited sample size, compensation, training and development were not found to be beneficial to improve the organizational performance.

Importantly, the moderation analysis of Islamic principle supports to enhance the organizational performance through compensation, performance appraisal, selection and recruitment and training and development. Though, the moderation of Islamic principle between the relationship of employee involvement and organizational performance has not shown any significant consequences for the Islamic banks of Pakistan.

This study provides a model for positive association between different HRM practices and firms. With the help of this structural equation model technique, it was identified that the most of the Islamic practices of HR has significant effects on the organizational performance. Further it suggests that the Islamic Banks have to work on the Islamic HR practices to maintain their performance in the organizations (B. K. Dhar et al., 2018). Further the study suggests that the managers of organizations have to provide great focus on the training and development side of the organization keeping is view the Islamic principles as these principles improves the relationship between these variables which is evident from the results. When a company provides relevant training to the employees i.e. according to their needs, only then they would be able to perform their job in a proper way and as per the expectations of the management.

Secondly the compensation is another major factor the managers should focus on. Islamic principles need to be followed again which providing monetary benefits as it motivates them to perform more actively and accurately. Thus the managers have to concentrate on the Islamic side while offering monetary benefits as should set certain strategies in their organizations to provide proper financial support to their employees so that their organization would grow.

\section{Limitations of the Research}

First and the foremost limitation of the current study is that the quantification of performance and Islamic work practice of the organization is done through the perception of the employees, as it is unidirectional. Furthermore, the size of the sample is quite small due to limited number of full fledge Islamic banks in Karachi, Pakistan. Moreover, the focus of the study revolves around the perspective of Karachi, Pakistan only.

\section{Future Research}

Initially, the study recommends analyzing the mediation of organizational support or supervisor support between the relationships in order to curtain off the deliberate understandings for the Islamic banks of Pakistan. Secondly, the enhancement in the size of sample will surely help to generalize the findings of the study. Thirdly, if the researchers follow qualitative approach, it will provide some important and in-depth understandings about the aspects that will help to improve the organizational performance of the Islamic banking industry in Pakistan. 


\section{References}

Abdul Cader, A. (2017). Islamic principles of conflict management: A model for human resource management. International Journal of Cross Cultural Management, 17(3), 345-363

Albrecht, S. L., Bakker, A. B., Gruman, J. A., Macey, W. H., \& Saks, A. M. (2015). Employee engagement, human resource management practices and competitive advantage: An integrated approach. Journal of Organizational Effectiveness: People and Performance, 2(1), 7-35

Ali, A. J., \& Al-Owaihan, A. (2008). Islamic work ethic: a critical review. Cross cultural management: An international Journal, 15(1), 5-19

AL-Qudah, M. K. M., Osman, A., Ab Halim, M. S., \& Al-Shatanawi, H. A. (2014). The Effect of Human Resources Planning and Training and Development on Organizational Performance in the Government Sector in Jordan. International Journal of Academic Research in Business and Social Sciences, 4(4), 79-85

Amin, M., Ismail, W. K. W., Rasid, S. Z. A., \& Selemani, R. D. A. (2014). The impact of human resource management practices on performance: Evidence from a Public University. The TQM Journal, 26(2), 125142

Azmi, I. A. G. (2010). Islamic human resource practices and organizational performance: A preliminary finding of Islamic organizations in Malaysia. Journal of Global Business and Economics, 1(1), 27-42

Bindabel, W., Patel, A., \& Yekini, C. O. (2017). The challenges faced by integrating Islamic corporate governance in companies of Gulf countries with non-Islamic companies across border through merger and acquisition

Birdi, K. S. 2005. No idea? Evaluating the Effectiveness of Creativity Training. Journal of European Industrial Training, $102-111$.

Bronston T. Mayes, Treena Gillespie Finney, Thomas W. Johnson, Jie Shen \& Lin Yi (2017) The effect of human resource practices on perceived organizational support in the People's Republic of China, The International Journal of Human Resource Management, 28:9, 1261-1290, DOI: 10.1080/09585192.2015.1114768

Cohen, L., Manion, L., \& Morrison, K. (2013). Research methods in education: Routledge

Darwish, T. K., Singh, S., \& Wood, G. (2016). The impact of human resource practices on actual and perceived organizational performance in a Middle Eastern emerging market. Human Resource Management, 55(2), 261-281

Delaney, J. T., \& Huselid, M. A. (1996). The impact of human resource management practices on perceptions of organizational performance. Academy of Management journal, 39(4), 949-969

Driskell, J. E. 2011. Effectiveness of Different Detection Training: A Meta - Analysis. Psychology, Crime and Law $10,1-19$.

Dhar, B. K., Masruki, R., Mutalib, M., Rahouma, H. M., Sobhani, F. A., \& Absar, M. M. N. (2018). Mediating Effect of Organizational Commitment Between Islamic Human Resource Practices and Organizational Performance Among Islamic Banks of Bangladesh. The Journal of Muamalat and Islamic Finance Research, 54-65

Dhar, R. L. (2015). The effects of high performance human resource practices on service innovative behaviour. International Journal of Hospitality Management, 51, 67-75

Fesharaki, F., \& Sehhat, S. (2018). Islamic human resource management (iHRM) enhancing organizational justice and employees' commitment: Case of a Qard al-Hasan bank in Iran. Journal of Islamic Marketing, 9(1), 204-218

Fornell, C., \& Larcker, D. F. (1981). Structural equation models with unobservable variables and measurement error: Algebra and statistics. Journal of marketing research, 18(3), 382-388

Hair, J. F., Black, W. C., Babin, B. J., Anderson, R. E., \& Tatham, R. L. (2006). SEM: Confirmatory Factor Analysis. Multivariate data analysis. Pearson Prentice Hall, Upper Saddle River, 770-842

Hair, J. F., Black, W., Babin, B., Anderson, R., \& Tatham, R. (2010). SEM: An introduction. Multivariate data analysis: A global perspective, 629-686

Hair, J. F., Ringle, C. M., \& Sarstedt, M. (2011). PLS-SEM: Indeed a silver bullet. Journal of Marketing theory and Practice, 19(2), 139-152 
Hair, J. F., Sarstedt, M., Hopkins, L., \& G. Kuppelwieser, V. (2014). Partial least squares structural equation modeling (PLS-SEM) An emerging tool in business research. European Business Review, 26(2), 106-121

Hashim, J. (2009). Islamic revival in human resource management practices among selected Islamic organisations in Malaysia. International Journal of Islamic and Middle Eastern Finance and Management, 2(3), 251-267

Hashim, J. (2010). Human resource management practices on organisational commitment: The Islamic perspective. Personnel Review, 39(6), 785-799.

Henseler, J., Hubona, G., \& Ray, P. A. (2016). Using PLS path modeling in new technology research: updated guidelines. Industrial Management \& Data Systems, 116(1), 2-20

Henseler, J., Ringle, C. M., \& Sarstedt, M. (2015). A new criterion for assessing discriminant validity in variancebased structural equation modeling. Journal of the academy of marketing science, 43(1), 115-135

Hussain, T., \& Rehman, S. S. (2013). Do human resource management practices inspire employees' retention?. Research Journal of Applied Sciences, Engineering and Technology, 6(19), 3625-3633

Razimi, M. S. B. A., Noor, M. M., \& Daud, N. M. (2014). The concept of dimension in human resource management from Islamic management perspective. Middle-East Journal of Scientific Research, 20(9), 1175-1182

Madison, K., Daspit, J. J., Turner, K., \& Kellermanns, F. W. (2018). Family firm human resource practices: Investigating the effects of professionalization and bifurcation bias on performance. Journal of Business Research, 84, 327-336

Mbogho, I. M. (2012). Assessment of the impact of compensation of organizational performance: A case of Kenya Ports Authority (Thesis). Retrieved from https://ir-library.ku.ac.ke/handle/123456789/6002

Moideenkutty, U., Al-Lamki A. \& Murthy Y. S. R. (2011). HRM practices and organizational performance in Oman. Personnel Review, 40(2), 239-251

Mostafa, A. M. S., Gould-Williams, J. S., \& Bottomley, P. (2015). High-performance human resource practices and employee outcomes: the mediating role of public service motivation. Public Administration Review, 75(5), 747-757

Habib Rana, M., \& Shaukat Malik, M. (2016). Human resource management from an Islamic perspective: a contemporary literature review. International Journal of Islamic and Middle Eastern Finance and Management, 9(1), 109-124

Knies, E., Boselie, P., Gould-Williams, J., \& Vandenabeele, W. (2017). Strategic human resource management and public sector performance: context matters: Taylor \& Francis

Rana, M. H., \& Malik, M. S. (2017a). Impact of HR Practices on Organizational Performance: Moderating Roles of Islamic Principles: Multan: Alfalah Institute of Banking Finance

Rana, M. H., \& Malik, M. S. (2017b). Impact of human resource (HR) practices on organizational performance: Moderating role of Islamic principles. International Journal of Islamic and Middle Eastern Finance and Management, 10(2), 186-207

Ringle, C. M., Sarstedt, M., \& Straub, D. (2012). A critical look at the use of PLS-SEM in MIS Quarterly. MIS Quarterly (MISQ), 36(1), 3-14

Sarwar, S., \& Abugre, J. B. (2013). An assessment of islamic work ethics of employees in organizations: insights from the united arab emirates. Problems of Management in the 21st Century. 6, 60-72

Saleem, Z., Malik, M. T., \& Khattak, S. R. (2016). Principles of Effective Management According to Quran and Sunnah

Salleh, M. J. (2012). Islamic principles of administration: implications on practices in organization. Unpublished manuscript, International Islamic University, Malaysia.

Suib, F. H., \& Said, M. F. (2017). A review of Islamic work ethics and spirituality concepts in service industry. Journal of Nusantara Studies (JONUS), 2(2), 282-294

Wong, K. K.-K. (2013). Partial least squares structural equation modeling (PLS-SEM) techniques using SmartPLS. Marketing Bulletin, 24(1), 1-3

Zikmund, W. G., Babin, B. J., Carr, J. C., \& Griffin, M. (2013). Business research methods: Cengage Learning 